\title{
MACROECONOMIC VARIABLES INFLUENCING HOUSING PRICES IN VILNIUS
}

\author{
Alfredas LAURINAVIČIUS (D) ${ }^{1}$, Antanas LAURINAVIČIUS (D) ${ }^{2, *}$, \\ Algimantas LAURINAVIČIUS (10) ${ }^{2}$ \\ ${ }^{1}$ Department of Roads, Faculty of Environmental Engineering, Vilnius Gediminas Technical University, \\ Vilnius, Lithuania \\ ${ }^{2}$ Department of Finance, Faculty of Economics and Business Administration, Vilnius University, \\ Vilnius, Lithuania
}

Received 30 April 2021; accepted 09 November 2021; first published online 02 December 2021

\begin{abstract}
The way macroeconomic variables such as unemployment/GDP per capita/inflation/wages/internal migration influenced housing prices (nominal house prices and housing rent prices) in Vilnius in 2006-2019 has been investigated in the research. Conditions under which different macroeconomic variables could influence housing prices were established in the research. Lower unemployment, higher GDP per capita and inflation rate were all related to higher nominal house prices in Vilnius. Higher GDP per capita, wages and internal migration were positively related to housing rent prices in Vilnius. Analyzed macroeconomic variables all together explained 88 percent of variance of nominal house prices in Vilnius over the period of 2006-2019 and 80 percent of variance of housing rent prices in Vilnius over the same period.
\end{abstract}

Keywords: nominal house prices, housing rent prices, rental yield, internal migration, stock price index.

\section{Introduction}

Pace of economic development of Lithuania was very rapid though even more uneven in last decades. However, growth rate depended much on region and more especially on city. In the same period, along with growing income housing prices (i.e., nominal house prices and housing rent prices) increased even more. Increase in prices was also very uneven, the same way as income growth (Laurinavičius et al., 2018, 2021). Thus, the article analyzes if macroeconomic variables (such as unemployment/GDP per capita/inflation/wages/internal migration) have a statistically significant impact on housing prices.

Research importance. Answers to the above-mentioned questions would help to identify which economic and social policy measures would be most effective to tackle the problem of increasing Vilnius housing prices, and which ones - in general - would benefit to the country's and its regions' economic development and sustainable growth.

Therefore, the aim of the research is to estimate the impact of macroeconomic variables on housing prices. This is why the article analyzes how macroeconomic variables influenced housing prices in Vilnius in 2006-2019.
First, correlation between macroeconomic variables and housing prices indicators (nominal house prices and housing rent prices) was calculated. Later on, influence of different macroeconomic variables on housing prices have been identified using simple and multiple regressions.

\section{Background}

Many scientists (Apergis, 2003; Goodhart \& Hofmann, 2008; Hirata et al., 2013; Ong \& Chang, 2013; and others) found impact of country's economic condition on real estate prices. Liu and $\mathrm{Ma}$ (2021) assessed determinants of housing prices in China. Their finding suggests that land price, loans of real estate developers, per capita saving and the proportion of people with college or above educational degrees significantly drive up house prices, while the number of unemployed population has a significant negative impact. These five variables account for $72 \%$ of variance in house prices across the country. Other economic fundamentals such as inflation, interest rate, gross domestic product (GDP) per capita, and rent cost do not have significant influences on house prices.

${ }^{*}$ Corresponding author. E-mail: antanas.laurinavicius@evaf.vu.lt 
Al-Masum and Lee (2019) find evidence that market fundamentals such as gross disposable income, housing supply, unemployment rate and gross domestic product are the key long-run determinants of Sydney housing prices, reflecting that Sydney housing prices, in general, can be explained by market fundamentals in the long run.

Coskun et al. (2020) find that housing rent and construction costs are positively related and real mortgage interest rate is negatively associated with Turkish housing prices in the long run.

Duan et al. (2021) show that both an increase in the money supply and a decrease in the mortgage rates lead to a rise in housing prices in the long term in Beijing.

The analysis of housing prices in New York State, USA, in 1999-2008 showed that the 30-year interest rate and inflation have statistically significant effects on housing prices. Interest rate has the highest effect, contributing $5.0 \%$ of variance in the first month to $8.5 \%$ in the twelfth. Unemployment rate has the next greatest influence followed by Dow Jones Industrial Average and inflation (Mohan et al., 2019).

Rehman et al. (2020) analyzing housing market of Portugal with quarterly data from 1998 to 2019, show that in the long term, unemployment and interest rates are negatively related and that population, inflation and money supply are positively associated with housing prices.

Demographic factors have been revealed to be an important factor for the housing prices (Capozza et al., 2002; Egert \& Mihaljek, 2007). In the short run, migration flows have a positive impact on housing prices because of the growth of populations in the receptive locations. However, in the long run, the growth of the population through births is only reflected in the housing demand twenty years later (Panagiotidis \& Printzis, 2016).

Migration has also been revealed to be an important factor of the price changes in the housing market (Gonzalez \& Ortega, 2012; Accetturo et al., 2014; Sá, 2015; Cochrane \& Poot, 2019; Snieška et al., 2019; Sharpe, 2019; Tyrcha, 2020). Using the metropolitan area as the unit of analysis, Saiz (2007) finds that immigration flows raise house prices and rents: immigration volumes on the order of $1 \%$ of total population raise these $1.0 \%$ and $2.9-3.4 \%$, respectively. As it is shown in next chapters, we find the increase of rent prices even bigger for Vilnius.

Larkin et al. (2019) analyse immigration's impact on house prices in 14 destination countries and find that immigration increases house prices. On the contrary, Sá (2015) finds that the same 1 percentage point increase in immigrant volumes as a percent of total population lowers house prices by $1.7 \%$. Braakmann (2019) finds variation in the effect that reflects the socioeconomic status of immigrants. He finds that the immigration decreases house prices for units below a region's median, but has no effect on those above the median.

Wang et al. (2017) found that an increase in internal migration by $1 \%$ would lead to a growth in housing prices of around $0.7 \%$. Pavlov and Somerville (2020) show that immigrants can raise neighborhood house prices (at least in the case of the wealthy immigrants).

Unemployment rate can have both a direct and an indirect effect on the housing prices (Gan \& Zhang, 2013). Schnure (2005) finds that an increase in unemployment rate by one percentage point leads to $1 \%$ decrease in housing price for US. As it is shown in next chapters, we find this decrease thrice bigger for Vilnius.

Tomal (2021) finds that among the studied determinants only two, describing unemployment rate and standard of apartments, are significant in all Polish counties.

The effects of inflation on real estate prices are identified by many researchers (e.g., Tsatsaronis \& Zhu, 2004; Tan \& Chen, 2013). They find that investment in real estate sector is a good hedge against inflation and the depreciation of money. Kuang and Liu (2015) found that housing prices were positively related to inflation (their findings were based on panel data of 35 major Chinese cities from 1996 to 2010). Yu and Huang (2016) concluded that the central and western cities in China responded to the change of HPI more obviously than eastern cities or a particular first-tier city. On the other hand, Tang et al. (2019) didn't find any long-term relationship between housing prices and inflation in 29 large Chinese cities.

People's expectations are also important determinants of real estate prices as well. $\mathrm{Ma}$ (2010) provides a psychological explanation that the main driving force of soaring house price is people's expectation that house price will continue to increase; Wen and Goodman (2013) and Hjalmarsson and Osterholm (2020) get similar findings. While it is impossible to measure behavioral factors precisely, the previous returns of different assets are frequently included in similar models.

Ionascu et al. (2021) analyze the relationship between housing prices and real estate market transparency in 21 European metropolitan areas for the period 20042016. Results indicate that a decrease in transparency level is associated with an increase in house prices, especially in the Eastern metropolitan areas (Bratislava, Bucharest, Warsaw and Zagreb).

Literature review suggests that, depending on region and analyzed period, different variables influence housing prices. This is the reason why, given the framework described in the first section, next two sections of the article analyze which specific variables out from those mentioned above influence housing prices in Vilnius.

\section{Methodology}

\subsection{Research scope and period}

Housing prices are defined in this study as nominal house prices and housing rent prices (Organisation for Economic Co-operation and Development, 2021). Data of 2006-2019 are analyzed in this article (Table A1 in Appendix). 2006 was chosen as a starting point as data on housing rent prices, used in this survey, are provided by Aruodas.lt only since 2006. 2019 is last year when data 
on macroeconomic variables are available. Only data on housing prices and OMX Vilnius GI stock price index are available for 2020 that is why only 3.1 section of research analyzes period of 2006-2020, and 3.2-3.4 sections analyze period of 2006-2019.

\subsection{Data}

Nominal house prices in Vilnius are taken from database of UAB Ober-Haus (2020). Nominal house prices are delivered in euros per 1 square metre (EUR/sqm) in each analyzed year.

Housing rent prices (apartments for rent) in Vilnius are taken from publicly available online database Aruodas. lt which is administered by UAB Diginet LTU. It is the largest housing rent website in Lithuania. Housing rent prices are presented in EUR/sqm per month in each analyzed year. One major limitation which has to be taken into account is that publicly available online database Aruodas.lt represents supply side of housing rent prices, and finally agreed market price can be lower. On the other hand, this tends to be less important when dynamics are analyzed as changes in supply price correspond to changes in finally agreed market price.

OMX Vilnius GI stock price index is taken from Nasdaq Baltic stock exchange and reflects stock prices of Lithuanian companies listed on Nasdaq Baltic stock exchange.

Unemployment rates are taken from Lithuanian Department of Statistics (hereinafter Statistics Lithuania). Unemployment rates are presented in percentage of people at the age of 15 years and over in Vilnius in each analyzed year. Statistics Lithuania evaluates unemployment regarding the data of employment survey.

GDP per capita in actual prices in Vilnius region when comparing to national average was taken from Statistics Lithuania. Those data present ratio of GDP per capita in actual prices in Vilnius region compared to national average.

Data on inflation in Lithuania has been taken from the World Bank database. Inflation is measured by the consumer price index and it reflects the annual percentage change in the cost to the average consumer of acquiring a basket of goods and services. The Laspeyres formula is generally used.

Data on wages was taken from Statistics Lithuania. Those data present monthly net wages in Vilnius. Data on internal migration (arrivals) was also taken from Statistics Lithuania. Those data show annual number of people who moved into Vilnius from other Lithuanian cities and towns.

However, it is important to notice that the analysis of macroeconomic variables influencing housing prices in Vilnius was based primarily on real economy variables, whereas financial sector variables were not analyzed. Such financial sector variables which were not analyzed included down payments required by banks and mortgage availability.

On the other hand, interest rates had a positive correlation with housing prices in Vilnius in 2006-2019 and this was determined by growing interest rates before the crisis of 2008-2009 and diminishing interest rates after the crisis. The pattern of housing prices was similar in both periods, that is why the correlation was positive. However, literature analysis show that this cannot be true in the long term, this was rather a coincidence, and this is the reason why the impact of interest rates of home loans on housing prices in Vilnius was not analyzed more in depth in this article.

\subsection{Methods}

Dynamic and graphic analysis of nominal house prices and housing rent prices in Vilnius in 2006-2020 was conducted first. Then a linear Pearson correlation coefficient was calculated between those two variables. The parameters of a simple linear regression, intercept and slope, were evaluated next using ordinary least squares method. Later on, simple linear regression equations were calculated and prognostic models were created. Finally, Student $t$-test was used to evaluate significance of regression parameters (Huber, 2004).

Stationarity of time series was checked. For that reason, an augmented Dickey-Fuller (ADF) test was conducted. The augmented Dickey-Fuller (ADF) statistic, used in the test, is a negative number. The more negative it is, the stronger the rejection of the hypothesis that there is a unit root at some level of confidence.

In order to compare housing rent prices to nominal house prices rental yield was calculated as a ratio between housing rent prices and nominal house prices. Rental yield dynamic and graphic analysis in Vilnius in 2006-2020 was conducted. Then, housing yield was calculated as a sum of rental yield and yearly changes in nominal house prices. Finally, housing yield in Vilnius was compared to OMX Vilnius GI stock price index in yearly and cumulative forms.

The relationship between housing prices and stock prices was analyzed in a later stage of research. First, a linear Pearson correlation coefficient was calculated between OMX Vilnius GI stock price index on the one hand and nominal house prices and housing rent prices in Vilnius on the other hand. Then, impact of lagged stock price data on housing prices was evaluated. Finally, dynamic and graphic analysis was conducted.

Last and the most important stage of research was designed to analyze the impact of macroeconomic variables on nominal house prices and housing rent prices. For that purpose, linear Pearson correlation coefficients between macroeconomic variables and housing prices were calculated. Nominal house prices and housing rent prices were considered to be dependent variables and selected macroeconomic variables were considered to be independent:

a) unemployment rate,

b) GDP per capita,

c) inflation,

d) wages,

e) internal migration (arrivals). 
Linear Pearson correlation coefficient ranges from -1 to $1 .-1$ and 1 show functional relationship, 0 indicates no dependence at all. Values greater than 0.5 (or less than -0.5 ) show averagely strong positive or negative relationship. Relationship is very strong with values higher than 0.7 (or less than -0.7 respectively).

Determination coefficients were evaluated when squaring correlation coefficients. Coefficients of determination indicate which part of variance of a factor (housing prices) is explained by other factors (macroeconomic variables).

Later on, simple linear regression equations were calculated, and prognostic models were created for relationships with significant correlation coefficients.

Finally, statistically significant variables (that Student's $t$-test calculated value was below 0.05 ) were included into a multiple linear regression model. Because of multicollinearity of independent variables, it can be difficult to evaluate impact of correlated independent variables on the dependent variable. This is why multicollinearity of independent variables was checked using VIF (variance inflation factor) test. If calculated VIF value was lower than 5 then there was no problem of multicollinearity. When VIF ranges from 5 to 10 then multicollinearity can be suspected. And when VIF is higher than 10 then an independent variable must be removed from further analysis (Kutner et al., 2004; Sheather, 2009).

Autocorrelation of residuals, heteroskedasticity of residuals and normality of distribution of residuals were also checked. The Durbin-Watson (DW) statistic was used to test autocorrelation in the residuals from regression analyses. The Durbin-Watson statistic always has a value ranging between 0 and 4 . A value of 2.0 indicates there is no autocorrelation detected in the sample. Values from 0 to less than 2 mean positive autocorrelation and values from 2 to 4 mean negative autocorrelation.

White's test was used to detect heteroskedasticity. It was checked if White's test statistic is statistically significant. If it was statistically significant, it would count against the null hypothesis of homoskedasticity and residuals may have been heteroskedastic.

Frequency distribution for residuals was used to test the normality of distribution of residuals. Null hypothesis of normal distribution was tested. If it was statistically significant, it would count against the null hypothesis of normality of distribution of residuals.

All calculations done by the authors were performed using MS Excel and statistical package Gretl.

\section{Results and discussion}

\subsection{Analysis of housing prices in Vilnius}

Dynamic (monthly) analysis of housing prices in Vilnius is shown in Figure 1. Housing rent prices are represented in EUR/sqm per month and nominal house prices in EUR/sqm are divided by 200 to better correspond the scale of Figure 1.

It can be stated that in pre-crisis and crisis period (2006-2009) dynamics of housing rent prices and nominal

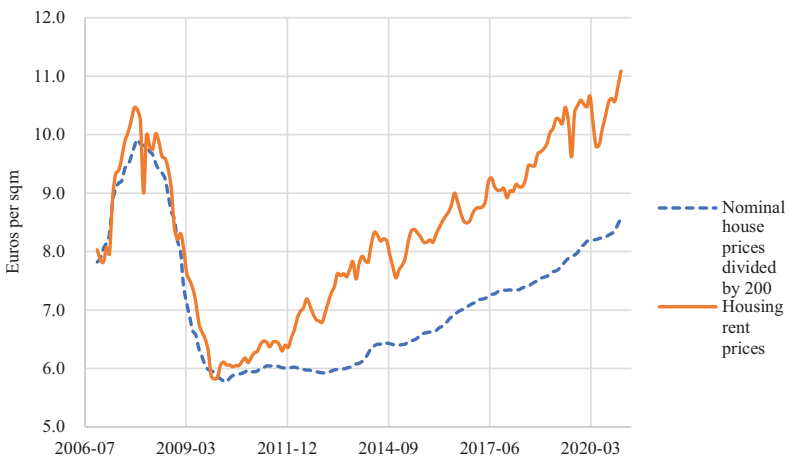

Figure 1. Dynamics of housing prices in Vilnius in 2006-2020

house prices almost coincided. Later on, housing rent prices and nominal house prices had both upward trend but housing rent prices have risen faster than nominal house prices which means that either housing rent is overpriced in Vilnius or nominal house prices are undervalued.

Correlation coefficient between housing rent prices and nominal house prices in Vilnius is positive and very strong and is equal to 0.82 . Coefficient of determination is 0.67 and it means that two thirds of housing rent prices can be explained by nominal house prices in Vilnius (and vice versa).

However, correlation does not show causality. That is why two regression analyses were carried out. Nominal house prices were considered to be an independent variable and housing rent prices were considered to be a dependent variable in the first analysis and the opposite in the second regression analysis. The results of both analyses are presented in Table 1.

Table 1. Coefficients of simple linear regressions between housing prices in Vilnius in 2006-2020

\begin{tabular}{|l|c|c|}
\hline Independent variable & $\begin{array}{c}\text { Nominal house } \\
\text { prices }\end{array}$ & $\begin{array}{c}\text { Housing rent } \\
\text { prices }\end{array}$ \\
\hline Intercept & 1.203 & 312.943 \\
\hline Slope & 0.005 & 133.573 \\
\hline$P$-value of $T$-test & 0.000 & 0.000 \\
\hline
\end{tabular}

It can be stated that both regressions are statistically significant. Regression equations are described below:

$$
\begin{aligned}
& \text { RENT = } 1.203+0.005 B U Y ; \\
& B U Y=312.943+133.573 R E N T,
\end{aligned}
$$

where: RENT is housing rent prices in EUR/sqm per month in Vilnius in 2006-2020; BUY is nominal house prices in EUR/sqm in Vilnius in 2006-2020.

Thus, first regression Equation (1) shows that nominal house prices need to rise by $200 \mathrm{EUR} / \mathrm{sqm}$ in order that housing rent prices would rise by $1 \mathrm{EUR} / \mathrm{sqm}$ per month. Second regression Equation (2) which represents income approach shows that nominal house prices will rise by almost $134 \mathrm{EUR} / \mathrm{sqm}$ when housing rent prices rise by $1 \mathrm{EUR} / \mathrm{sqm}$ per month. Different results were driven by different forms of graphs of nominal house prices and housing rent prices (see Figure 1). 
Figure 1 also suggests the idea that time series of housing rent prices (RENT) and/or nominal house prices $(B U Y)$ can be non-stationary. For that reason, an augmented Dickey-Fuller (ADF) test was conducted. ADF test with constant and trend statistic tau for RENT is -5.06 and for $B U Y$ is -2.64 (both sample sizes are 170). The augmented Dickey-Fuller (ADF) statistic, used in the test, is a negative number. The more negative it is, the stronger the rejection of the hypothesis that there is a unit root at some level of confidence. Critical value for ADF with trend when sample size is between 100 and 250 is -3.44 at the $95 \%$ confidence level and -4.01 at the $99 \%$ confidence level. Hence, statistic tau for RENT of -5.06 is more negative than the tabulated critical values, so at the $99 \%$ level the null hypothesis of a unit root will be rejected which means that time series of housing rent prices (RENT) is stationary. The situation is quite different with nominal house prices $(B U Y)$. Statistic tau for $B U Y$ of -2.64 is less negative than the tabulated critical value of -3.44 , so at the $95 \%$ level the null hypothesis of a unit root cannot be rejected which means that time series of nominal house prices $(B U Y)$ can be non-stationary.

One way to solve the problem of a non-stationarity of time series is to take their first differences for testing. When we test first differences of nominal house prices $\left(B U Y_{D I F}\right), A D F$ test with constant and trend statistic tau is equal to -3.98 which is more negative than the tabulated critical value of -3.44 at the $95 \%$ confidence level. Hence, at the $95 \%$ level the null hypothesis of a unit root will be rejected which means that time series of first differences of nominal house prices $\left(B U Y_{D I F}\right)$ is stationary.

If we use first differences of nominal house prices $\left(B U Y_{D I F}\right)$ instead of nominal house prices $(B U Y)$, results of first and second regression analyses which had been presented in Table 1 can be rewritten as follows (Table 2):

Table 2. Coefficients of simple linear regressions between first differences of nominal house prices and housing rent prices in Vilnius in 2006-2020

\begin{tabular}{|l|c|c|}
\hline Independent variable & $\begin{array}{c}\text { First differences } \\
\text { in nominal house } \\
\text { prices }\end{array}$ & $\begin{array}{c}\text { Housing rent } \\
\text { prices }\end{array}$ \\
\hline Intercept & 8.322 & -22.802 \\
\hline Slope & 0.014 & 2.842 \\
\hline$P$-value of $T$-test & 0.010 & 0.010 \\
\hline
\end{tabular}

It can be stated that both regressions are statistically significant. Regression equations are described below:

$$
\begin{aligned}
& R E N T=8.322+0.014 B U Y_{D I F} ; \\
& B U Y_{D I F}=-22.802+2.842 R E N T,
\end{aligned}
$$

where: RENT is housing rent prices in EUR/sqm per month in Vilnius in 2006-2020; $B U Y_{D I F}$ is first differences of nominal house prices in EUR/sqm in Vilnius in 20062020 (in other words nominal house prices growth rate).

If we compare regression Equation (1a) to regression Equation (1) we can see that nominal house prices growth rate has almost 3 times bigger impact on housing rent prices than the impact of nominal house prices (slope of 0.014 in Equation (1a) vs. slope of 0.005 in Equation (1). On the contrary, housing rent prices have much greater impact on nominal house prices (slope of Equation (2)) than on nominal house prices growth rate (slope of Equation (2a)).

Another way to analyze if housing rent is overpriced in Vilnius or nominal house prices are undervalued is to calculate rental yield. Rental yield in Vilnius in 2006-2020 is presented in Figure 2.

Figure 2 shows that residential property rental yield in Vilnius was in the range of 6.0-6.5\% in 2006-2011 and increased to $7.0-8.0 \%$ in $2013-2020$. It is important to notice that even though financial crisis of 2008 hit nominal house prices very hard (40\% down in 2008-2009, see Figure 1) rental yield in Vilnius did not deteriorate at all and remained stable at the same pre-crisis level of $6.0-6.5 \%$ (see Figure 2). This happened because housing rent prices shrank in Vilnius exactly at the same pace and level as nominal house prices (see once again Figure 1).

Which level of rental yield is more sustainable? Or, once again, housing rent is overpriced in Vilnius or nominal house prices are undervalued? Another way to answer this question is to compare rental yield (and change in nominal house prices) to OMX Vilnius GI stock price index. Comparison is presented in Figure 3.

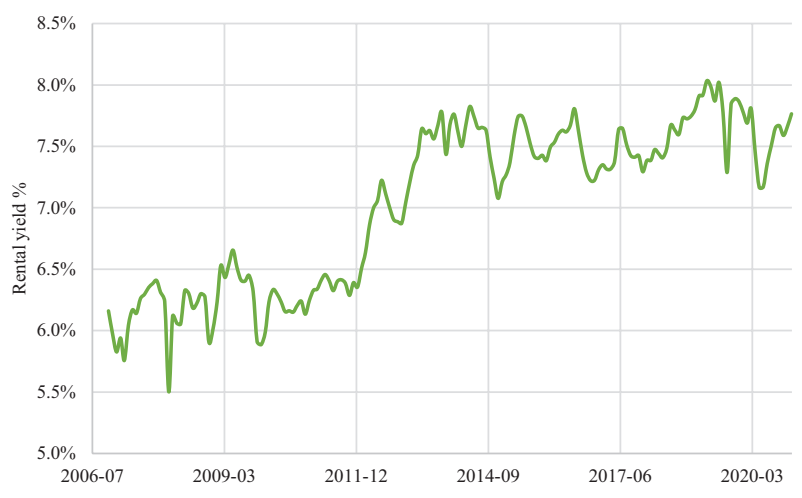

Figure 2. Dynamics of rental yield in Vilnius in 2006-2020

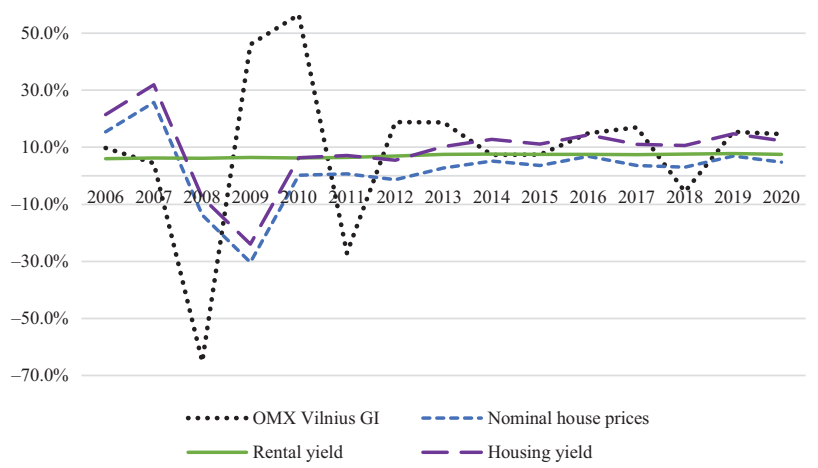

Figure 3. Yearly changes in OMX Vilnius GI stock price index and nominal house prices in Vilnius, rental yield and housing yield in Vilnius in 2006-2020 


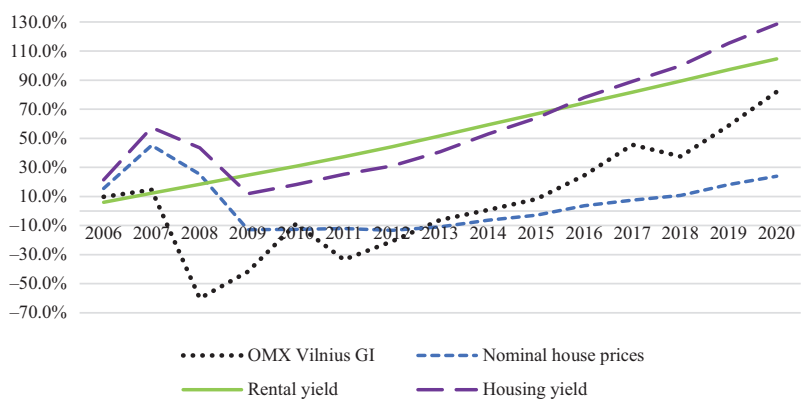

Figure 4. Cumulative changes in OMX Vilnius GI stock price index and nominal house prices in Vilnius, rental yield and housing yield in Vilnius in 2006-2020

Housing yield is calculated as a sum of change in nominal house prices and a rental yield. Housing yield can be then compared to change in OMX Vilnius GI stock price index. However, as yearly values fluctuate a lot it is difficult to see a trend and to draw conclusions. This inconvenience can be solved when analyzing cumulative data which is presented in Figure 4.

It can be seen that cumulative rental yield in Vilnius in 2006-2020 exceeds cumulative change in OMX Vilnius GI stock price index which suggests that residential property rent in Vilnius has been a better investment form than buying and holding Lithuanian stocks in 2006-2020. In addition to that, this result was obtained without taking into account changes in nominal house prices. If we add both (cumulative change in nominal house prices in Vilnius and cumulative rental yield) the result will exceed cumulative change in OMX Vilnius GI stock price index even more. Sure, OMX Vilnius GI stock price index was seriously hit by 2008 financial crisis but nominal house prices in Vilnius also lost 40\% of their value in 2008-2009. This raises a question what is the relationship between housing prices in Vilnius and OMX Vilnius GI stock price index in general.

Results of correlation analysis between housing prices in Vilnius and OMX Vilnius GI stock price index are described in Table 3.

It can be stated that OMX Vilnius GI stock price index is positively correlated with housing prices in Vilnius in 2006-2020. Correlation is weak when analyzing nominal house prices and very strong when analyzing housing rent

Table 3. Correlation and determination coefficients between OMX Vilnius GI stock price index and housing prices in Vilnius in 2006-2020

\begin{tabular}{|l|c|c|}
\hline \multicolumn{1}{|c|}{ Variables } & $\begin{array}{c}\text { Correlation } \\
\text { coefficients }\end{array}$ & $\begin{array}{c}\text { Determination } \\
\text { coefficients }\end{array}$ \\
\hline Nominal house prices & 0.41 & 0.17 \\
\hline $\begin{array}{l}\text { Nominal house prices } \\
\text { lagged by 1 year }\end{array}$ & 0.69 & 0.47 \\
\hline Housing rent prices & 0.77 & 0.59 \\
\hline $\begin{array}{l}\text { Housing rent prices } \\
\text { lagged by 1 year }\end{array}$ & 0.90 & 0.81 \\
\hline
\end{tabular}

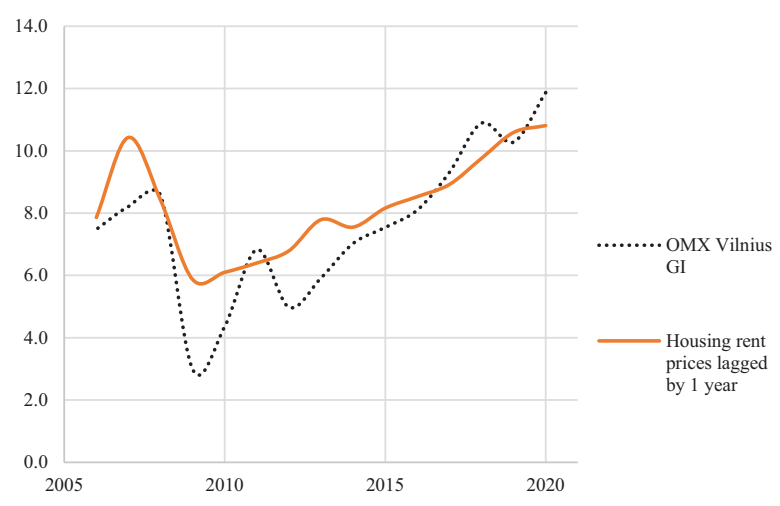

Figure 5. Dynamics of OMX Vilnius GI stock price index and housing rent prices lagged by 1 year in Vilnius in 2006-2020

prices. Moreover, correlation in even stronger when analyzing lagged housing prices, in that case, it is averagely strong for lagged nominal house prices and very strong for lagged housing rent prices. The explanation behind that phenomena could be that stock prices are a leading indicator which anticipates economic cycle including housing prices some time in advance.

Determination coefficients show that, for example, changes in stock prices can explain more than three quarters of changes in housing rent prices lagged by 1 year. The relationship between OMX Vilnius GI stock price index and housing rent prices lagged by 1 year is presented in Figure 5. Housing rent prices are represented in EUR/ sqm per month and OMX Vilnius GI stock price index is divided by 60 to better correspond the scale of Figure 5 .

Figure 5 clearly shows what a similar pattern is taken by OMX Vilnius GI stock price index and housing rent prices lagged by 1 year except that housing rent prices avoid sharp declines which are common for stock prices during crisis periods.

\subsection{Correlation analysis between macroeconomic variables and housing prices}

Correlation and determination coefficients between macroeconomic variables and housing prices in Vilnius were evaluated (Tables 4 and 5).

It can be specified that there is a very strong negative correlation between unemployment rate and nominal

Table 4. Correlation and determination coefficients between macroeconomic variables and nominal house prices in Vilnius in 2006-2019

\begin{tabular}{|l|c|c|}
\hline \multicolumn{1}{|c|}{ Variables } & $\begin{array}{c}\text { Correlation } \\
\text { coefficients }\end{array}$ & $\begin{array}{c}\text { Determination } \\
\text { coefficients }\end{array}$ \\
\hline Unemployment rate & -0.72 & 0.52 \\
\hline GDP per capita & 0.69 & 0.48 \\
\hline Inflation & 0.52 & 0.28 \\
\hline Wages & 0.05 & 0.00 \\
\hline $\begin{array}{l}\text { Internal migration } \\
\text { (arrivals) }\end{array}$ & -0.04 & 0.00 \\
\hline
\end{tabular}


Table 5. Correlation and determination coefficients between macroeconomic variables and housing rent prices in Vilnius in 2006-2019

\begin{tabular}{|l|c|c|}
\hline \multicolumn{1}{|c|}{ Variables } & $\begin{array}{c}\text { Correlation } \\
\text { coefficients }\end{array}$ & $\begin{array}{c}\text { Determination } \\
\text { coefficients }\end{array}$ \\
\hline Unemployment rate & -0.87 & 0.76 \\
\hline GDP per capita & 0.25 & 0.06 \\
\hline Inflation & 0.11 & 0.01 \\
\hline Wages & 0.54 & 0.29 \\
\hline $\begin{array}{l}\text { Internal migration } \\
\text { (arrivals) }\end{array}$ & 0.49 & 0.24 \\
\hline
\end{tabular}

house prices in Vilnius and averagely strong positive correlation between GDP per capita and inflation on the one hand and nominal house prices on the other hand.

It can be stated that, like in previous case, there is a very strong negative correlation between unemployment rate and housing rent prices in Vilnius and a weak positive correlation between GDP per capita and housing rent prices. Unlike in previous case, there is an averagely strong positive correlation between monthly wages and internal migration (arrivals) on the one hand and housing rent prices on the other hand.

Coefficients of determination in both cases (nominal house prices and housing rent prices) show that unemployment rate can alone explain more than a half of variance in nominal house prices and more than three quarters of variance in housing rent prices. Likewise, GDP per capita can explain almost a half of nominal house prices, and wages and internal migration can each explain a quarter of housing rent prices.

\subsection{Simple regression analysis between macroeconomic variables and housing prices}

After having found out that highest correlation coefficients are between unemployment rate, GDP per capita, inflation and nominal house prices, and unemployment rate, GDP per capita, wages and internal migration (arrivals) and housing rent prices, those variables were included into the regression analysis. Dependent variable is considered to be nominal house prices in first regression analysis and housing rent prices in second regression analysis. Independent variables are considered to be unemployment rate, GDP per capita, inflation, wages and internal migration.

The results of regression analysis between macroeconomic variables and nominal house prices in Vilnius are presented in Table 6.
Table 6. Coefficients of simple linear regressions between macroeconomic variables and nominal house prices in Vilnius in 2006-2019

\begin{tabular}{|l|c|c|c|}
\hline \multicolumn{1}{|c|}{$\begin{array}{c}\text { Independent } \\
\text { variable }\end{array}$} & $\begin{array}{c}\text { Unemployment } \\
\text { rate }\end{array}$ & $\begin{array}{c}\text { GDP per } \\
\text { capita }\end{array}$ & Inflation \\
\hline Intercept & 1730.46 & -6093.95 & 1286.34 \\
\hline Slope & -49.95 & 51.37 & 43.44 \\
\hline$P$-value of $T$-test & 0.00 & 0.00 & 0.00 \\
\hline
\end{tabular}

It can be stated that all three regressions are statistically significant. Regression equations are described below:

$$
\begin{aligned}
& B U Y=1730.46-49.95 U N E M P L ; \\
& B U Y=-6093.95+51.37 G D P ; \\
& B U Y=1286.34+43.44 I N F L,
\end{aligned}
$$

where: $B U Y$ is nominal house prices in EUR/sqm in Vilnius in 2006-2019; UNEMPL represents unemployment rate in Vilnius; GDP stands for GDP per capita in Vilnius region; INFL is inflation rate in Lithuania.

Thus, Equation (3) suggests that growth in unemployment rate in Vilnius by 1 percentage point reduces nominal house prices in Vilnius by almost 50 EUR/sqm. On the contrary, increase in GDP per capita in Vilnius region by 1 percentage point when comparing to national average increases nominal house prices in Vilnius by over 50 EUR/sqm Equation (4). Finally, increase in national inflation rate by 1 percentage point increases nominal house prices in Vilnius by more than 43 EUR/sqm Equation (5).

The results of regression analysis between macroeconomic variables and housing rent prices in Vilnius are presented in Table 7.

$P$-value of $T$-test of unemployment rate shows that the regression is statistically insignificant, other three regressions are statistically significant. Statistically significant regression equations are described below:

$$
\begin{aligned}
& \text { RENT }=-9.1583+0.1179 \text { GDP } ; \\
& R E N T=4.6198+0.0056 \text { WAGES } ; \\
& \text { RENT }=4.9213+0.0004 M I G R,
\end{aligned}
$$

where: RENT is housing rent prices in EUR/sqm per month in Vilnius in 2006-2019; GDP represents GDP per capita in Vilnius region; WAGES stands for monthly wages in Vilnius; and MIGR is internal migration (arrivals) to Vilnius.

Thus, Equation (6) suggests that increase in GDP per capita in Vilnius region by 1 percentage point when comparing to national average increases housing rent prices in

Table 7. Coefficients of simple linear regressions between macroeconomic variables and housing rent prices in Vilnius in 2006-2019

\begin{tabular}{|l|c|c|c|c|}
\hline \multicolumn{1}{|c|}{ Independent variable } & Unemployment rate & GDP per capita & Wages & $\begin{array}{c}\text { Internal migration } \\
\text { (arrivals) }\end{array}$ \\
\hline Intercept & 10.4328 & -9.1583 & 4.6198 & 4.9213 \\
\hline Slope & -0.3780 & 0.1179 & 0.0056 & 0.0004 \\
\hline$P$-value of $T$-test & 0.0754 & 0.0000 & 0.0000 & 0.0000 \\
\hline
\end{tabular}


Table 8. Tests of simple linear regression equations

\begin{tabular}{|l|c|c|c|c|c|c|}
\hline & Equation (3) & Equation (4) & Equation (5) & Equation (6) & Equation (7) & Equation (8) \\
\hline Autocorrelation, DW & 0.84 & 0.93 & 0.92 & 0.60 & 0.89 & 0.91 \\
\hline Autocorrelation, $p$-value & 0.003 & 0.006 & 0.007 & 0.000 & 0.004 & 0.004 \\
\hline Heteroskedasticity, $p$-value & 0.632 & 0.692 & 0.101 & 0.862 & 0.158 & 0.580 \\
\hline Normality, $p$-value & 0.042 & 0.876 & 0.526 & 0.958 & 0.098 & 0.304 \\
\hline
\end{tabular}

Vilnius by $0.12 \mathrm{EUR} / \mathrm{sqm}$ per month. Similarly, increase in net monthly wages in Vilnius by 1 euro increases housing rent prices in Vilnius by 0.56 eurocent per square metre per month. And finally, increase in internal migration (arrivals) to Vilnius by one thousand people increases housing rent prices in Vilnius by $0.4 \mathrm{EUR} / \mathrm{sqm}$ per month.

Tests of most important assumptions of regression Equations (3) to (8) are presented in Table 8.

It can be seen that all models deal with an issue of positive autocorrelation. When autocorrelated residuals are found to be present, then one of the first remedial measures should be to investigate the omission of a key predictor variable. This is done in next section 3.4 "Multiple regression analysis".

As for assumption of heteroskedasticity, none of the regression analyses cannot reject the null hypothesis that residuals are homoscedastic, this is why there is no problem of heteroskedasticity of residuals.

Residuals in all regressions seem to be normal except the $3^{\text {rd }}$ one where the null hypothesis about the normality of residuals cannot be rejected only at the confidence level of $99 \%$; however, it can be rejected at the confidence level of $95 \%$.

\subsection{Multiple regression analysis between macroeconomic variables and housing prices}

Multiple linear regression model was established using statistically significant independent variables. Dependent variable is considered to be nominal house prices in first multiple regression analysis and housing rent prices in second multiple regression analysis. Independent variables are considered to be unemployment rate, GDP per capita and inflation in first multiple regression analysis and GDP per capita, wages and internal migration (arrivals) in second multiple regression analysis.

Independent variables multicollinearity analysis results are described in Table 9.

As VIF coefficients are less than 5 the problem of multicollinearity of independent variables does not exist in both multiple regression analyses. Thus, two multiple linear regression models with three independent variables in each can be made. The results are presented in Table 10.

Correlation coefficients of both multiple linear regression models are positive and very strong (varying from 0.90 to 0.94 ). Correspondingly, determination coefficients vary from 0.80 to 0.88 . It indicates that unemployment rate, GDP per capita and inflation all together explain $88 \%$ of variance of nominal house prices in Vilnius in 2006-
Table 9. VIF (variance inflation factors) of independent variables

\begin{tabular}{|l|c|c|}
\hline \multicolumn{1}{|c|}{$\begin{array}{c}\text { Independent } \\
\text { variables }\end{array}$} & $\begin{array}{c}\text { Multiple regression } \\
\text { of nominal house } \\
\text { prices }\end{array}$ & $\begin{array}{c}\text { Multiple regression } \\
\text { of housing rent } \\
\text { prices }\end{array}$ \\
\hline Unemployment rate & 1.1 & 1.6 \\
\hline GDP per capita & 1.4 & 3.6 \\
\hline Inflation & 1.3 & 3.9 \\
\hline Wages & & \\
\hline $\begin{array}{l}\text { Internal migration } \\
\text { (arrivals) }\end{array}$ & & \\
\hline
\end{tabular}

Table 10. Linear multiple regression statistics

\begin{tabular}{|l|c|c|c|c|}
\hline & \multicolumn{2}{|c|}{$\begin{array}{c}\text { Multiple regression } \\
\text { of nominal house } \\
\text { prices }\end{array}$} & \multicolumn{2}{|c|}{$\begin{array}{c}\text { Multiple regression } \\
\text { of housing rent } \\
\text { prices }\end{array}$} \\
\hline & $\begin{array}{c}\text { Coeffi- } \\
\text { cient }\end{array}$ & $P$-value & $\begin{array}{c}\text { Coeffi- } \\
\text { cient }\end{array}$ & $P$-value \\
\hline Multiple $R$ & \multicolumn{2}{|c|}{0.94} & \multicolumn{2}{c|}{0.90} \\
\hline$R$ Square & \multicolumn{2}{|c|}{0.88} & \multicolumn{2}{c|}{0.80} \\
\hline Intercept & -2805.80 & 0.073 & -59.52 & 0.001 \\
\hline $\begin{array}{l}\text { Unemployment } \\
\text { rate }\end{array}$ & -42.00 & 0.000 & & \\
\hline GDP per capita & 30.15 & 0.010 & 0.41 & 0.000 \\
\hline Inflation & 25.03 & 0.037 & & \\
\hline Wages & & & 0.006 & 0.028 \\
\hline $\begin{array}{l}\text { Internal migration } \\
\text { (arrivals) }\end{array}$ & & & 0.0004 & 0.043 \\
\hline
\end{tabular}

2019. Likewise, GDP per capita, monthly net wages and internal migration (arrivals) all together can explain 80\% of housing rent prices in Vilnius in the same period.

It can also be stated that in both multiple linear regression models all independent variables are statistically significant. On the contrary, intercept is statistically significant only in the model of housing rent prices. Multiple linear regression equations for both models are presented below:

$$
\begin{aligned}
& B U Y=-2805.80-42.00 U N E M P L+30.15 G D P+ \\
& 25.03 I N F L ; \\
& R E N T=-59.52+0.41 G D P+0.006 \text { WAGES + } \\
& 0.0004 M I G R,
\end{aligned}
$$

where: $B U Y$ is nominal house prices in EUR/sqm in Vilnius in 2006-2019; RENT is housing rent prices in EUR/sqm per month in Vilnius in 2006-2019; UNEMPL 
represents unemployment rate; GDP stands for GDP per capita; INFL is inflation rate; WAGES represents monthly wages; and MIGR stands for internal migration (arrivals).

It can be stated that the values of independent variables' coefficients of multiple linear regression are lower than those calculated in simple linear regression analysis where dependent variable is nominal house prices (Equation (9) vs. Equations (3), (4) and (5)). As for housing rent prices, the situation is different. Coefficient of GDP per capita in multiple regression is almost 4 times higher than in simple regression (Equation (10) vs. Equation (6)). At the same time, coefficients of monthly wages and internal migration (arrivals) are identical in multiple and simple regressions (Equation (10) vs. Equations (7) and (8)).

Tests of most important assumptions of regression Equations (9) and (10) are presented in Table 11.

Table 11. Tests of multiple linear regression equations

\begin{tabular}{|l|c|c|}
\hline & Equation (9) & Equation (10) \\
\hline Autocorrelation, DW & 2.08 & 2.01 \\
\hline Autocorrelation, $p$-value & 0.284 & 0.226 \\
\hline Heteroskedasticity, $p$-value & 0.161 & 0.846 \\
\hline Normality, $p$-value & 0.852 & 0.127 \\
\hline
\end{tabular}

It can be seen that the problem of autocorrelation, all as expected, was solved when adding new predictor variables. Moreover, both multiple regression analyses cannot reject the null hypothesis that residuals are homoscedastic, this is why there is no problem of heteroskedasticity of residuals. And finally, residuals in both regressions seem to be normal.

\section{Conclusions}

Many scientists found statistically significant and direct impact of country's economic conditions (GDP per capita, unemployment rate, household income and housing credit, change of interest rates, inflation, FDI flows) on real estate prices. Demographic indicators, such as population growth rate and migration trends have a stable relationship with housing price. People's expectations are found to be important determinants of real estate prices as well.

The way macroeconomic variables such as unemployment/GDP per capita/inflation/wages/internal migration influenced housing prices in Vilnius in 2006-2019 has been analyzed by the authors. First of all, correlation between macroeconomic variables and housing prices indicators (nominal house prices and housing rent prices) was calculated. Later on, simple and multiple regression equations were calculated. Stationarity of time series (ADF test), autocorrelation of residuals (DW test), heteroskedasticity of residuals, normality of distribution of residuals and multicollinearity of variables (VIF test) were checked.

It can be stated that in pre-crisis and crisis period (2006-2009) dynamics of housing rent prices and nominal house prices perfectly coincided in Vilnius. Later on, housing rent prices and nominal house prices had both upward trend but housing rent prices have risen faster than nominal house prices.

Nominal house prices growth rate had almost 3 times bigger impact on housing rent prices than the impact of nominal house prices. On the contrary, housing rent prices had much greater impact on nominal house prices than on nominal house prices growth rate in Vilnius.

Residential property rental yield in Vilnius was in the range of $6.0-6.5 \%$ in $2006-2011$ and increased to $7.0-$ $8.0 \%$ in $2013-2020$. It is important to notice that even though financial crisis of 2008 hit nominal house prices very hard (40\% down in 2008-2009) rental yield in Vilnius did not deteriorate at all and remained stable at the same pre-crisis level of 6.0-6.5\%. This happened because housing rent prices shrank in Vilnius exactly at the same pace and level as nominal house prices.

OMX Vilnius GI stock price index was positively correlated with housing prices in Vilnius in 2006-2020. Correlation is weak when analyzing nominal house prices and very strong when analyzing housing rent prices. Moreover, correlation in even stronger when analyzing housing prices lagged by 1 year. In that case, correlation is averagely strong for lagged nominal house prices and very strong for lagged housing rent prices. The explanation behind that phenomena could be that stock prices are a leading indicator which anticipates economic cycle including housing prices some time in advance.

Lower unemployment, higher GDP per capita and inflation rate are all related to higher nominal house prices in Vilnius. Higher GDP per capita, wages and internal migration are positively related to housing rent prices in Vilnius.

Coefficients of determination in both cases (nominal house prices and housing rent prices) show that unemployment rate can alone explain more than a half of variance in nominal house prices and more than three quarters of variance in housing rent prices. Likewise, GDP per capita can explain almost a half of nominal house prices, and wages and internal migration can each explain a quarter of housing rent prices.

Increase in unemployment rate in Vilnius by 1 percentage point reduces nominal house prices in Vilnius by almost $50 \mathrm{EUR} / \mathrm{sqm}$. On the contrary, increase in GDP per capita in Vilnius region by 1 percentage point when compared to national average increases nominal house prices in Vilnius by over 50 EUR/sqm. Finally, increase in national inflation rate by 1 percentage point increases nominal house prices in Vilnius by more than $43 \mathrm{EUR} / \mathrm{sqm}$.

Increase in GDP per capita in Vilnius region by $1 \%$ increases housing rent prices in Vilnius by $0.12 \mathrm{EUR} / \mathrm{sqm}$ per month. Similarly, increase in net monthly wages in Vilnius by 1 euro increases housing rent prices in Vilnius by 0.56 eurocent per square metre per month. And finally, increase in internal migration (arrivals) to Vilnius by one thousand people increases housing rent prices in Vilnius by $0.4 \mathrm{EUR} / \mathrm{sqm}$ per month. 
Analyzed macroeconomic variables all together explain $88 \%$ of variance of nominal house prices in Vilnius over the period of 2006-2019 and 80\% of variance of housing rent prices in Vilnius over the same period.

\section{Author contributions}

Alfredas Laurinavičius contributed to the conception and design of the article and team-leading; Antanas Laurinavičius and Algimantas Laurinavičius contributed to the drafting of the article and revising it, analysis and interpretation of data for the article.

\section{Disclosure statement}

The authors declare no conflict of interest.

\section{References}

Accetturo, A., Manaresi, F., Mocetti, S., \& Olivieri, E. (2014). Don't stand so close to me: the urban impact of immigration. Regional Science and Urban Economics, 45(1), 45-56. https://doi.org/10.1016/j.regsciurbeco.2014.01.001

Al-Masum, M. A., \& Lee, C. L. (2019). Modelling housing prices and market fundamentals: evidence from the Sydney housing market. International Journal of Housing Markets and Analysis, 12(4), 746-762.

https://doi.org/10.1108/IJHMA-10-2018-0082

Apergis, N. (2003). Housing prices and macroeconomic factors: prospects within the European Monetary Union. International Real Estate Review, 6(1), 63-74.

https://doi.org/10.1080/1350485032000100260

Aruodas. (2020). Real estate price statistics. https://en.aruodas. lt/kainu-statistika/

Braakmann, N. (2019). Immigration and the property market: evidence from England and Wales. Real Estate Economics, 47(2), 509-533. https://doi.org/10.1111/1540-6229.12151

Capozza, D. R., Hendershott, P. H., Mack, C., \& Mayer, C. J. (2002). Determinants of real house price dynamics (Working Paper Series No. 9262). National Bureau of Economic Research. https://doi.org/10.3386/w9262

Cochrane, W., \& Poot, J. (2019). The effects of immigration on local housing markets (Working Paper in Economics No. 7/19). University of Waikato.

Coskun, Y., Seven, U., Ertugrul, H. M., \& Alp, A. (2020). Housing price dynamics and bubble risk: the case of Turkey. Housing Studies, 35(1), 50-86.

https://doi.org/10.1080/02673037.2017.1363378

Duan, J. L., Tian, G. J., Yang, L., \& Zhou, T. (2021). Addressing the macroeconomic and hedonic determinants of housing prices in Beijing Metropolitan Area, China. Habitat International, 113, 102374.

https://doi.org/10.1016/j.habitatint.2021.102374

Egert, B., \& Mihaljek, D. (2007). Determinants of house prices in Central and Eastern Europe (BIS Working Papers No. 236). Bank for International Settlements.

Gan, L., \& Zhang, Q. (2013). Market thickness and the impact of unemployment on housing market outcomes (Working Paper No. 19564). National Bureau of Economic Research. https://doi.org/10.3386/w19564

Gonzalez, L., \& Ortega, F. (2012). Immigration and housing booms: evidence from Spain. Journal of Regional Science, 53(1), 37-59. https://doi.org/10.1111/jors.12010
Goodhart, C., \& Hofmann, B. (2008). House prices, money, credit and the macroeconomy (Working Paper Series No. 888). European Central Bank. https://doi.org/10.1093/oxrep/grn009

Hirata, H., Kose, M. A., Otrok, C., \& Terrones, M. E. (2013). Global house price fluctuations: synchronization and determinants (IMF Working Paper No. WP/13/18k). International Monetary Fund. https://doi.org/10.2139/ssrn.2295211

Hjalmarsson, E., \& Osterholm, P. (2020). Heterogeneity in households' expectations of housing prices - evidence from micro data. Journal of Housing Economics, 50, 101731. https://doi.org/10.1016/j.jhe.2020.101731

Huber, P. J. (2004). Robust statistics. John Wiley \& Sons.

Ionascu, E., Taltavull de La Paz, P., \& Mironiuc, M. (2021). The relationship between housing prices and market transparency. Evidence from the metropolitan European markets. Housing Theory \& Society, 38(1), 42-71. https://doi.org/10.1080/14036096.2019.1672577

Yu, H., \& Huang, Y. (2016). Regional heterogeneity and the trans-regional interaction of housing prices and inflation: evidence from China's 35 major cities. Urban Studies, 53(16), 3472-3492. https://doi.org/10.1177/0042098015617882

Kuang, W., \& Liu, P. (2015). Inflation and house prices: theory and evidence from 35 major cities in China. International Real Estate Review, 18(1), 217-240. https://doi.org/10.53383/100200

Kutner, M. H., Nachtsheim, C. J., \& Neter, J. (2004). Applied linear regression models (4th ed.). McGraw-Hill Irwin.

Larkin, M. P., Askarov, Z., Doucouliagos, H., Dubelaarb, C., Klona, M., Newton, J., Stanley, T. D., \& Vocino, A. (2019). Do house prices ride the wave of immigration? Journal of Housing Economics, 46, 101630.

https://doi.org/10.1016/j.jhe.2019.04.002

Laurinavičius, A., Laurinavičius, A., \& Laurinavičius, A. (2021). Impact of housing affordability and other socioeconomic variables on internal migration in Lithuania. International Journal of Strategic Property Management, 25(2), 102-114. https://doi.org/10.3846/ijspm.2020.13604

Laurinavičius, A., Laurinavičius, A., \& Smilga, E. (2018). Lietuvos strateginio iškilimo gairès. Vilniaus universiteto leidykla.

Liu, M., \& Ma, Q.-P. (2021). Determinants of house prices in China: a panel-corrected regression approach. Annals of Regional Science, 67, 47-72. https://doi.org/10.1007/s00168-020-01040-z

$\mathrm{Ma}$, Q. P. (2010). Housing market in China's growth recovery and house price determination. In 21st CEA (UK) and 2nd CEA (Europe) Annual Conference Global Economic Recovery: The Role of China and Other Emerging Economies (pp. 12-13), University of Oxford, UK.

Mohan, S., Hutson, A., MacDonald, I., \& Lin, C. C. (2019). Impact of macroeconomic indicators on housing prices. International Journal of Housing Markets and Analysis, 12(6), 1055-1071. https://doi.org/10.1108/IJHMA-09-2018-0070

Ober-Haus. (2020). Housing prices in Lithuania. https://www. ober-haus.lt/en/ohbi-calculator/

Ong, T. S., \& Chang, Y. S. (2013). Macroeconomic determinants of Malaysian housing market. Human and Social Science Research, 1(2), 119-127.

Organisation for Economic Co-operation and Development. (2021). Housing prices (indicator). https://doi.org/10.1787/63008438-en

Panagiotidis, T., \& Printzis, P. (2016). On the macroeconomic determinants of the housing market in Greece: a VECM approach. International Economics and Economic Policy, 13(3), 387-409. https://doi.org/10.1007/s10368-016-0345-3

Pavlov, A., \& Somerville, T. (2020). Immigration, capital flows and housing prices. Real Estate Economics, 48(3), 915-949. https://doi.org/10.1111/1540-6229.12267 
Rehman, S. K. U., Moutinho, N. F. L., \& Alves, J. M. A. (2020). The relationship between Portugues economy indicators and housing prices. Journal of Spatial and Organizational Dynamics, 8(4), 270-286.

Sá, F. (2015). Immigration and house prices in the UK. The Economic Journal, 125(587), 1393-1424. https://doi.org/10.1111/ecoj.12158

Saiz, A. (2007). Immigration and housing rents in American cities. Journal of Urban Economics, 61(2), 345-371. https://doi.org/10.1016/j.jue.2006.07.004

Schnure, C. (2005). Boom-bust cycles in housing: the changing role of financial structure IDEAS (Working Paper Series from RePEc). International Monetary Fund. https://doi.org/10.5089/9781451862195.001

Sharpe, J. (2019). Re-evaluating the impact of immigration on the U.S. rental housing market. Journal of Urban Economics, 111, 14-34. https://doi.org/10.1016/j.jue.2019.04.001

Sheather, S. (2009). A modern approach to regression with R. Springer. https://doi.org/10.1007/978-0-387-09608-7

Snieška, V., Navickas, V., \& Jegelavičiūtè, R. (2019). The interaction between the migration of human resources and the prices of housing: Lithuanian case. Transformations in Business \& Economics, 46(1), 199-213.

Tan, Z., \& Chen, M. (2013). House prices as indicators of monetary policy: evidence from China (Working Paper No. 488). Stanford University.
Tang, J., Ye, K., \& Qian, Y. (2019). Rethinking the relationship between housing prices and inflation: new evidence from 29 large cities in China. International Journal of Strategic Property Management, 23(3), 142-155.

https://doi.org/10.3846/ijspm.2019.7800

Tyrcha, A. (2020). Migration and housing markets - evidence from Sweden [Doctoral thesis]. Robinson College, Department of Land Economy, University of Cambridge.

https://doi.org/10.2139/ssrn.3394234

Tomal, M. (2021). Exploring the meso-determinants of apartment prices in Polish counties using spatial autoregressive multiscale geographically weighted regression. Applied Economics Letters, 1-9. https://doi.org/10.1080/13504851.2021.1891194

Tsatsaronis, K., \& Zhu, H. (2004). What drives housing price dynamics. Cross-country evidence. BIS Quarterly Review, 1, 65-78.

Wang, X., Hui, E., \& Sun, J. (2017). Population migration, urbanization and housing prices: evidence from the cities in China. Habitat International, 66, 49-56. https://doi.org/10.1016/j.habitatint.2017.05.010

Wen, H., \& Goodman, A. C. (2013). Relationship between urban land price and housing price: evidence from 21 provincial capitals in China. Habitat International, 40, 9-17. https://doi.org/10.1016/j.habitatint.2013.01.004

\section{Appendix}

Table A1. Data of analyzed variables in 2006-2019

\begin{tabular}{|c|c|c|c|c|c|c|c|c|}
\hline & $\begin{array}{c}\text { Nominal } \\
\text { house prices } \\
\text { in Vilnius, } \\
\text { EUR/sqm }\end{array}$ & $\begin{array}{c}\text { Housing } \\
\text { rent prices } \\
\text { in Vilnius, } \\
\text { EUR/sqm } \\
\text { per month }\end{array}$ & $\begin{array}{c}\text { OMX } \\
\text { Vilnius GI } \\
\text { stock price } \\
\text { index }\end{array}$ & $\begin{array}{c}\text { Unemploy- } \\
\text { ment rate in } \\
\text { Vilnius, } \%\end{array}$ & $\begin{array}{c}\text { GDP per capita } \\
\text { in Vilnius region } \\
\text { compared to } \\
\text { national average }\end{array}$ & $\begin{array}{c}\text { Inflation in } \\
\text { Lithuania, \% }\end{array}$ & $\begin{array}{c}\text { Net monthly } \\
\text { wages in } \\
\text { Vilnius, EUR } \\
\text { migration } \\
\text { (arrivals) to } \\
\text { Vilnius }\end{array}$ \\
\hline 2019 & 1616 & 10.59 & 712.1 & 3.0 & 145.2 & 2.3 & 942 & 12261 \\
\hline 2018 & 1512 & 9.76 & 616.9 & 3.3 & 144.4 & 2.7 & 820 & 11178 \\
\hline 2017 & 1468 & 8.92 & 653.3 & 3.1 & 142.8 & 3.7 & 748 & 10900 \\
\hline 2016 & 1417 & 8.53 & 558.5 & 3.7 & 145.0 & 0.9 & 685 & 11039 \\
\hline 2015 & 1326 & 8.16 & 486.0 & 5.2 & 145.6 & -0.9 & 639 & 10357 \\
\hline 2014 & 1280 & 7.55 & 452.4 & 6.1 & 145.5 & 0.1 & 614 & 8900 \\
\hline 2013 & 1218 & 7.79 & 421.6 & 7.1 & 145.0 & 1.0 & 584 & 9322 \\
\hline 2012 & 1185 & 6.79 & 355.1 & 8.9 & 143.2 & 3.1 & 563 & 10954 \\
\hline 2011 & 1202 & 6.40 & 298.8 & 10.5 & 142.7 & 4.1 & 543 & 7010 \\
\hline 2010 & 1193 & 6.10 & 409.7 & 13.0 & 145.9 & 1.3 & 529 & 6540 \\
\hline 2009 & 1192 & 5.87 & 261.8 & 11.5 & 147.9 & 4.5 & 539 & 6879 \\
\hline 2008 & 1711 & 8.42 & 179.3 & 5.3 & 149.5 & 10.9 & 560 & 7439 \\
\hline 2007 & 1983 & 10.43 & 514.2 & 3.4 & 153.8 & 5.7 & 465 & 6983 \\
\hline 2006 & 1578 & 7.86 & 492.7 & 2.9 & 151.2 & 3.7 & 389 & 6282 \\
\hline
\end{tabular}

